\title{
Renal Damage in the SHR/N-cp Type 2 Diabetes Model: Comparison of an Angiotensin-Converting Enzyme Inhibitor and Endothelin Receptor Blocker
}

\author{
Marie-Luise Gross, Eberhard Ritz, Arne Schoof, Burkhard Helmke, Amy Parkman, \\ Orien Tulp, Klaus Münter, and Kerstin Amann
}

Departments of Pathology (M-LG, AS, BH) and Internal Medicine (ER), University of Heidelberg, Heidelberg, Germany; Department of Bioscience and Biotechnology (AP), Drexel University Philadelphia, Pennsylvania; London College of Medicine, Technology and Research (OT), London, United Kingdom; Bayer AG (KM), Wuppertal, and Department of Pathology (KA), University of Erlangen, Erlangen, Germany

\begin{abstract}
SUMMARY: The pathomechanisms that cause renal damage in diabetes have not been completely clarified. Treatment with angiotensin-converting enzyme inhibitors (ACE-i) is highly effective but fails to completely prevent end-stage renal disease. The effects of $E T_{A}$-receptor blockers $\left(E T_{A}-R B\right)$ on renal damage are controversial and have rarely been investigated in type 2 diabetes. We compared the influence of the selective $\mathrm{ET}_{\mathrm{A}}-\mathrm{RB}$ LU135252 and the ACE-i Trandolapril on renal structure in the SHR/N-cp rat model of type 2 diabetes. Three-month-old male SHR/N-cp rats were left untreated or received daily either Trandolapril or LU135252. The experiment was terminated after 6 months. The glomerulosclerosis index; tubulointerstitial damage index; and glomerular geometry, glomerular cell number, and capillary density were investigated. Proliferating cell nuclear antigen and desmin expression of podocytes, renal mRNA expression of endothelin (ET-1) and transforming growth factor- $\beta$, blood pressure, and urine albumin excretion were measured. The glomerulosclerosis index was significantly higher in untreated diabetic animals than in the groups that were treated with $A C E-i$ and $E_{A}-R B$. There were analogous changes in tubulointerstitial damage index. Treatment with either substance comparably lowered urinary albumin excretion in diabetic SHR/N-cp. Podocyte and endothelial cell numbers per glomerulus decreased in untreated diabetic animals; this was prevented by the ACE-i but not by the $\mathrm{ET}_{\mathrm{A}}-\mathrm{RB}$. Glomerular capillary length density was lower in SHR/N-cp, and this was normalized by ACE-i only. Increased expression of desmin and proliferating cell nuclear antigen expression of podocytes in the SHR/N-cp was abrogated by ACE-i but not by $E T_{A}-R B$. Treatment with $A C E-i$ or $E T_{A}$-receptor antagonist resulted in less structural and functional alterations, but the $E T_{A}-R B$ was inferior to the ACE-i. This is particularly the case for podocyte changes pointing to angiotensin II-dependent pathomechanisms. (Lab Invest 2003, 83:1267-1277).
\end{abstract}

\begin{abstract}
$T \mathrm{n}$ the past two decades, an increasing incidence of 1 end-stage renal disease has been observed among patients with diabetes, particularly type 2 . The characteristic diabetic lesion in humans is Kimmelstiel-Wilson glomerulosclerosis accompanied by vascular and interstitial lesions. The pathomechanisms that lead to glomerulosclerosis have not been completely clarified. Recently, more interest has focused on podocyte loss as a key event responsible for progressive glomerular injury in diabetic nephropathy (Pagtalunan et al, 1997).

Administration of angiotensin-converting enzyme inhibitors (ACE-i) is the most effective therapeutic intervention to attenuate or halt progression of diabetic nephropathy, yet many patients still proceed to end-stage renal disease, so there is a need for alternative or complementary interventions. Renal cells
\end{abstract}

DOI: 10.1097/01.LAB.0000085188.23709.29

Received January 24, 2003

Address reprint requests to: Dr. Marie-Luise Gross, Department of Pathology, University of Heidelberg, Im Neuenheimer Feld 220/221, 69120 Heidelberg Germany.E-mail:Marie-Luise_Gross@med.uni-heidelberg.de produce ET-1 (Marsen et al, 1994), and cultured glomerular endothelial cells express $\mathrm{ET}_{\mathrm{B}}$ receptors (Hori et al, 1992). Furthermore $\mathrm{ET}_{\mathrm{A}}$ receptors are expressed in cultured mesangial cells (Takeda et al, 1992), and functional $\mathrm{ET}_{\mathrm{A}}$ receptors are also found on podocytes (Rebibou et al, 1992). This raises the issue of whether ET-receptor blockers (ET-RB) are beneficial, but the literature on their effects in diabetic nephropathy is controversial. Benigni et al (1998) described marked renoprotection in insulinopenic diabetes, but other authors reported negative results (Dhein et al, 2000; Hocher et al, 1998; Kelly et al, 2000). Little information is available concerning the role of ET-1 in models of type 2 diabetes. The aim of the present study was to compare the effect of an $\mathrm{ET}_{\mathrm{A}}-\mathrm{RB}$ with the well-established effect of an ACE-i on glomerular lesions in the SHR/N-cp model of type 2 diabetes.

\section{Results}

\section{Animal Data}

Nondiabetic control rats (lean) weighed significantly less than untreated diabetic animals (obese). Treat- 
ment with $A C E-i$ or $E T_{A}-R B$ had no influence on body weight. Blood glucose was significantly lower in nondiabetic compared with diabetic animals. Treatment had no effect on blood glucose. Systolic blood pressure was not different between untreated nondiabetic and diabetic rats. The ACE-i significantly reduced blood pressure in both nondiabetic and diabetic rats, whereas the $E T_{A}-R B$ had no significant effect on blood pressure. After 6 months, urinary albumin excretion was significantly lower in nondiabetic compared with diabetic rats; $A C E-i$ and $E T_{A}-R B$ reduced albuminuria in diabetic rats, but ACE-i treatment was more effective (Table 1).

\section{Morphologic Investigations}

Indices of Renal Damage. Diabetes was associated with a significantly higher glomerulosclerosis index in untreated rats. Both interventions reduced the glomerulosclerosis index significantly and comparably in nondiabetic and diabetic rats. The tubulointerstitial damage index (TBI) was significantly higher in diabetic rats compared with nondiabetic animals. In nondiabetic rats, either treatment failed to affect TBI; in diabetic animals, ACE-i reduced TBI significantly more effectively than $E T_{A}-R B$. The vascular damage index (VDI) was significantly higher in diabetic compared with nondiabetic rats. The interventions had no significant effect in nondiabetic rats. In diabetic rats, ACE-i but not $\mathrm{ET}_{\mathrm{A}}$-RB led to a significantly lower VDI (Table 2, Fig. 1).

Glomerular Volume. Mean glomerular volume was not significantly different in untreated diabetic compared with nondiabetic animals. In nondiabetic and diabetic rats, only $A C E-i$ but not $E_{A}-R B$ caused a lower glomerular volume (Table 2).

Stereologic Analysis in Semithin Sections. The length density, ie, capillary length per volume of the capillary tuft, is a sensitive indicator of capillary oblit- eration and was significantly lower in untreated diabetic compared with nondiabetic rats. It was normalized by ACE-i treatment but not by $E T_{A}-R B$. In untreated diabetic compared with nondiabetic rats, the mean number of podocytes per glomerulus was significantly lower and mean podocyte volume was significantly higher. In diabetic rats, only ACE-i prevented podocyte loss and led to lower mean podocyte volume, whereas $\mathrm{ET}_{\mathrm{A}}$-RB was not effective. In diabetic rats, the mesangial cell number per glomerulus was not significantly different, but the mean mesangial cell volume was significantly higher compared with nondiabetic rats, indicating hypertrophy of mesangial cells rather than hyperplasia. Both interventions prevented the increase in mean mesangial cell volume in diabetic rats, but only with ACE-i the values were close to normal.

The endothelial cell number per glomerulus was significantly lower in diabetic rats (193 \pm 15 in untreated diabetic versus $281 \pm 41$ in nondiabetic rats), but mean endothelial cell volume was higher in diabetic rats (Table 3 ). Both interventions significantly increased the number $\left(255 \pm 50\right.$ in $\mathrm{ET}_{\mathrm{A}}$-RB- and 270 \pm 49 in ACE-I-treated diabetic rats) and decreased the volume of endothelial cells (Table 3 ). In nondiabetic rats, no significant difference in mesangial and endothelial cell number or mean cell volume was seen, and interventions had no effect.

Ultrastructural Changes of the Glomerulus. With the use of electron microscopy, marked thickening of the glomerular basement membrane as well as nodular mesangial matrix deposition was seen in untreated diabetic animals compared with nondiabetic controls. In addition, podocyte hypertrophy and degeneration with cystic transformation of the cytoplasm and loss of foot processes were seen in untreated diabetic rats and to a lesser extent in $\mathrm{ET}_{\mathrm{A}}-\mathrm{RB}$-treated animals, but it was only in diabetic rats that were treated with ACE-i that these changes were absent (Fig. 2).

Table 1. Animal Data (at the End of the Experiment)

\begin{tabular}{|c|c|c|c|c|c|}
\hline Animal group & $\begin{array}{l}\text { Body weight } \\
\text { (g) }\end{array}$ & $\begin{array}{l}\text { Kidney weight } \\
\text { (g) }\end{array}$ & $\begin{array}{l}\text { Blood glucose } \\
\text { (mg/dl) }\end{array}$ & $\begin{array}{l}\text { Systolic blood } \\
\text { pressure } \\
(\mathrm{mmHg})\end{array}$ & $\begin{array}{c}\text { Urinary albumin } \\
\text { excretion } \\
\text { (mg/24 h) }\end{array}$ \\
\hline $\begin{array}{l}\text { Nondiabetic SHR/N-cp } \\
\quad(n=9)\end{array}$ & $489 \pm 41^{\star \dagger \ddagger}$ & $2.01 \pm 0.21$ & $99 \pm 4.8^{\star \dagger \ddagger}$ & $144 \pm 31$ & $33 \pm 14^{*}$ \\
\hline $\begin{array}{l}\text { Nondiabetic SHR/N-cp } \\
\quad+\mathrm{ET}_{\mathrm{A}}-\mathrm{RB}(n=8)\end{array}$ & $418 \pm 34^{\star \dagger \ddagger}$ & $1.4 \pm 0.24^{\ddagger}$ & $101 \pm 11.0^{\star \star \ddagger}$ & $152 \pm 45$ & $15 \pm 7.8^{\star \ddagger}$ \\
\hline $\begin{array}{l}\text { Nondiabetic SHR/N-cp } \\
\quad+\text { ACE-i }(n=13)\end{array}$ & $496 \pm 74^{\star \dagger \ddagger}$ & $1.54 \pm 0.29+* \ddagger$ & $87 \pm 17^{\star \dagger \ddagger}$ & $133 \pm 27^{\star}$ & $7.8 \pm 4.2^{\star \dagger \ddagger}$ \\
\hline $\begin{array}{l}\text { Diabetic SHR/N-cp } \\
\quad(n=7)\end{array}$ & $660 \pm 68$ & $2.27 \pm 0.21$ & $378 \pm 58.7$ & $154 \pm 19^{\dagger}$ & $177 \pm 77^{\dagger}$ \\
\hline $\begin{array}{c}\text { Diabetic SHR/N-cp + } \\
\mathrm{ET}_{\mathrm{A}}-\mathrm{RB}(n=9)\end{array}$ & $650 \pm 57$ & $1.9 \pm 0.31$ & $386 \pm 77$ & $149 \pm 22$ & $67 \pm 39^{*}$ \\
\hline $\begin{array}{l}\text { Diabetic SHR/N-cp + } \\
\quad \text { ACE-i }(n=12)\end{array}$ & $627 \pm 75$ & $1.91 \pm 0.22$ & $316 \pm 104$ & $132 \pm 34^{*}$ & $48 \pm 28^{*}$ \\
\hline ANOVA & $p<0.05$ & $p<0.05$ & $p<0.05$ & $p<0.05$ & $p<0.05$ \\
\hline
\end{tabular}

${ }^{*} p<0.05$ vs diabetic SHR/N-cp.

$+p<0.05$ vs diabetic SHR/N-cp + ACE-i.

$\neq p<0.05$ vs nondiabetic SHR/N-cp $+\mathrm{ET}_{\mathrm{A}}-\mathrm{RB}$. 
Table 2. Indices of Renal Damage and Glomerular Geometry

\begin{tabular}{|c|c|c|c|c|c|}
\hline Animal group & $\begin{array}{c}\text { GSI } \\
\text { (score } 0-4 \text { ) }\end{array}$ & $\begin{array}{c}\text { TBI } \\
\text { (score } 0-4 \text { ) }\end{array}$ & $\begin{array}{c}\text { VDI } \\
\text { (score } 0-4 \text { ) }\end{array}$ & $\begin{array}{c}\text { Total no. of } \\
\text { glomeruli per kidney }\end{array}$ & $\begin{array}{c}\text { Mean glomerular } \\
\text { volume }\left(\times 10^{6} \mu \mathrm{m}^{3}\right)\end{array}$ \\
\hline $\begin{array}{l}\text { Nondiabetic SHR/N-cp } \\
\quad(n=9)\end{array}$ & $0.79 \pm 0.1$ & $0.3 \pm 0.1^{\dagger}$ & $0.18 \pm 0.08$ & $27,987 \pm 3,595$ & $4.74 \pm 0.41$ \\
\hline $\begin{array}{l}\text { Nondiabetic SHR/N-cp } \\
\quad+\mathrm{ET}_{\mathrm{A}}-\mathrm{RB}(n=8)\end{array}$ & $0.46 \pm 0.04^{\star}$ & $0.3 \pm 0.16^{\dagger}$ & $0.1 \pm 0.03$ & $37,149 \pm 4,558$ & $3.86 \pm 0.55^{\S}$ \\
\hline $\begin{array}{l}\text { Nondiabetic SHR/N-cp } \\
\quad+\text { ACE-i }(n=13)\end{array}$ & $0.42 \pm 0.1^{\star \dagger}$ & $0.2 \pm 0.08^{\dagger}$ & $0.1 \pm 0.07$ & $34,874 \pm 1,753$ & $3.14 \pm 0.31^{*}$ \\
\hline $\begin{array}{l}\text { Diabetic SHR/N-cp } \\
\quad(n=7)\end{array}$ & $1.79 \pm 0.09^{\star \dagger \ddagger}$ & $2.73 \pm 0.12^{\star \dagger \ddagger}$ & $0.3 \pm 0.15^{\star \dagger \ddagger}$ & $22,032 \pm 4,064$ & $5.35 \pm 1.91^{\dagger}$ \\
\hline $\begin{array}{c}\text { Diabetic SHR/N-cp + } \\
\mathrm{ET}_{\mathrm{A}}-\mathrm{RB}(n=9)\end{array}$ & $0.82 \pm 0.12$ & $1.41 \pm 0.27^{\star \dagger}$ & $0.2 \pm 0.14^{\dagger}$ & $31,163 \pm 3,098$ & $4.14 \pm 0.59$ \\
\hline $\begin{array}{c}\text { Diabetic SHR/N-cp + } \\
\text { ACE-i }(n=12)\end{array}$ & $0.71 \pm 0.12$ & $0.98 \pm 0.25^{\star}$ & $0.1 \pm 0.06$ & $39,581 \pm 6,764$ & $3.58 \pm 0.90^{*}$ \\
\hline ANOVA & $p<0.05$ & $p<0.05$ & $p<0.05$ & n.s. & $p<0.05$ \\
\hline
\end{tabular}

${ }^{*} p<0.05$ vs nondiabetic SHR/N-cp.

${ }^{\dagger} p<0.05$ vs diabetic SHR/N-cp + ACE-i.

$\ddagger p<0.05$ vs diabetic SHR/N-cp $+\mathrm{ET}_{\mathrm{A}}-\mathrm{RB}$.
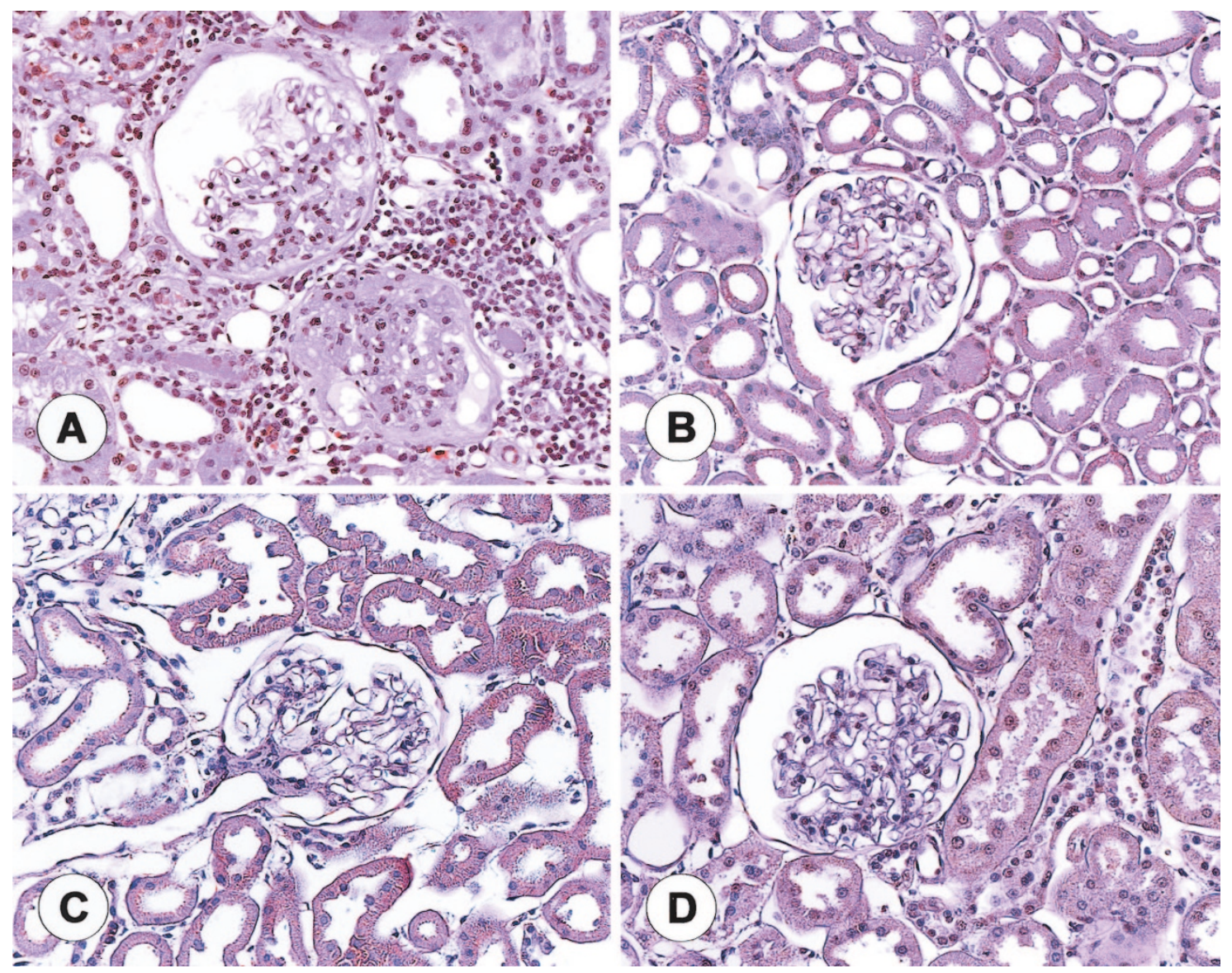

Figure 1.

A, Obese diabetic SHR/N-cp rat with marked sclerosis and attachment of the capillary tuft to the Bowman's capsula. Tubuli are dilated with atrophic epithelium, luminal deposition of eosinophilic material. Some additional interstitial fibrosis with scar around cell infiltrates. B, Lean nondiabetic control animal with normal glomerular and tubular structure. C, Glomeruli of $\mathrm{ET}_{\mathrm{A}}$-receptor blocker $\left(\mathrm{ET}_{\mathrm{A}}{ }^{-} \mathrm{RB}\right)$-treated diabetic obese SHR/N/-cp animal. Note only minor mesangial matrix expansion. No tubulointerstitial change. D, Glomeruli of angiotensin-converting enzyme inhibitor (ACE-i)-treated diabetic obese SHR/N-cp animal with some hypertrophy of mesangial cells. No tubulointerstitial changes. Original magnification, $\times 200$ (periodic acid-Schiff stain)

\section{Immunohistochemical Investigations}

Proliferating Cell Nuclear Antigen. Untreated diabetic animals had significantly more proliferating cell nuclear antigen (PCNA)-positive podocytes per glomerular profile than nondiabetic controls. $\mathrm{ET}_{\mathrm{A}}-\mathrm{RB}$ and ACE-i had no effect in nondiabetic rats, but in diabetic 


\begin{tabular}{|c|c|c|c|c|c|}
\hline Animal group & $\begin{array}{c}\mathrm{L}_{V} \\
\left(\mathrm{~mm} / \mathrm{mm}^{3}\right)\end{array}$ & $\begin{array}{l}\text { Podocyte } \\
\text { number per } \\
\text { glomerulus }\end{array}$ & $\begin{array}{l}\text { Mean podocyte } \\
\text { volume } \\
\left(\mu \mathrm{m}^{3}\right)\end{array}$ & $\begin{array}{l}\text { Mean mesangial } \\
\text { cell volume } \\
\left(\mu \mathrm{m}^{3}\right)\end{array}$ & $\begin{array}{l}\text { Mean endothelial } \\
\text { cell volume } \\
\left(\mu \mathrm{m}^{3}\right)\end{array}$ \\
\hline Nondiabetic SHR/N-cp $(n=9)$ & $9137 \pm 843^{\dagger}$ & $92 \pm 11.2^{\dagger}$ & $9470 \pm 4077^{\dagger}$ & $935 \pm 368^{\dagger}$ & $1253 \pm 161^{\S}$ \\
\hline $\begin{array}{l}\text { Nondiabetic SHR/N-cp + } \\
\quad \mathrm{ET}_{\mathrm{A}}-\mathrm{RB}(n=8)\end{array}$ & $9698 \pm 1451^{\dagger}$ & $77 \pm 12$ & $0,181 \pm 1,030^{\dagger}$ & $726 \pm 149^{\dagger}$ & $1020 \pm 102^{\dagger}$ \\
\hline $\begin{array}{l}\text { Nondiabetic SHR/N-cp + } \\
\text { ACE-i }(n=13)\end{array}$ & $9185 \pm 938^{\dagger}$ & $82 \pm 9.9^{\ddagger}$ & $9898 \pm 1451^{\dagger}$ & $939 \pm 93^{\dagger}$ & $1326 \pm 119^{\S}$ \\
\hline Diabetic SHR/N-cp $(n=7)$ & $7383 \pm 425^{\star}$ & $61 \pm 3.4^{* \dagger}$ & $15,519 \pm 3,011^{\star \ddagger}$ & $1223 \pm 101$ & $2213 \pm 301^{* \ddagger}$ \\
\hline $\begin{array}{l}\text { Diabetic SHR/N-cp }+\mathrm{ET}_{\mathrm{A}}-\mathrm{RB} \\
\quad(n=9)\end{array}$ & $8252 \pm 787^{\star \ddagger}$ & $57 \pm 8.4^{* \ddagger}$ & $16,703 \pm 2,664^{\star \ddagger}$ & $1050 \pm 220^{\dagger}$ & $1129 \pm 171^{\dagger}$ \\
\hline $\begin{array}{l}\text { Diabetic SHR/N-cp + ACE-i } \\
\quad(n=12)\end{array}$ & $9963 \pm 1280^{\dagger}$ & $79 \pm 11.4^{\dagger}$ & $9991 \pm 3010^{\dagger}$ & $867 \pm 135^{\dagger}$ & $1090 \pm 277^{\dagger}$ \\
\hline ANOVA & $p<0.05$ & $p<0.05$ & $p<0.05$ & $p<0.05$ & $p<0.05$ \\
\hline
\end{tabular}

${ }^{*} p<0.05$ vs nondiabetic SHR/N-cp.

$+p<0.05$ vs diabetic SHR/N-cp.

$\neq p<0.05$ vs diabetic SHR/N-cp + ACE.
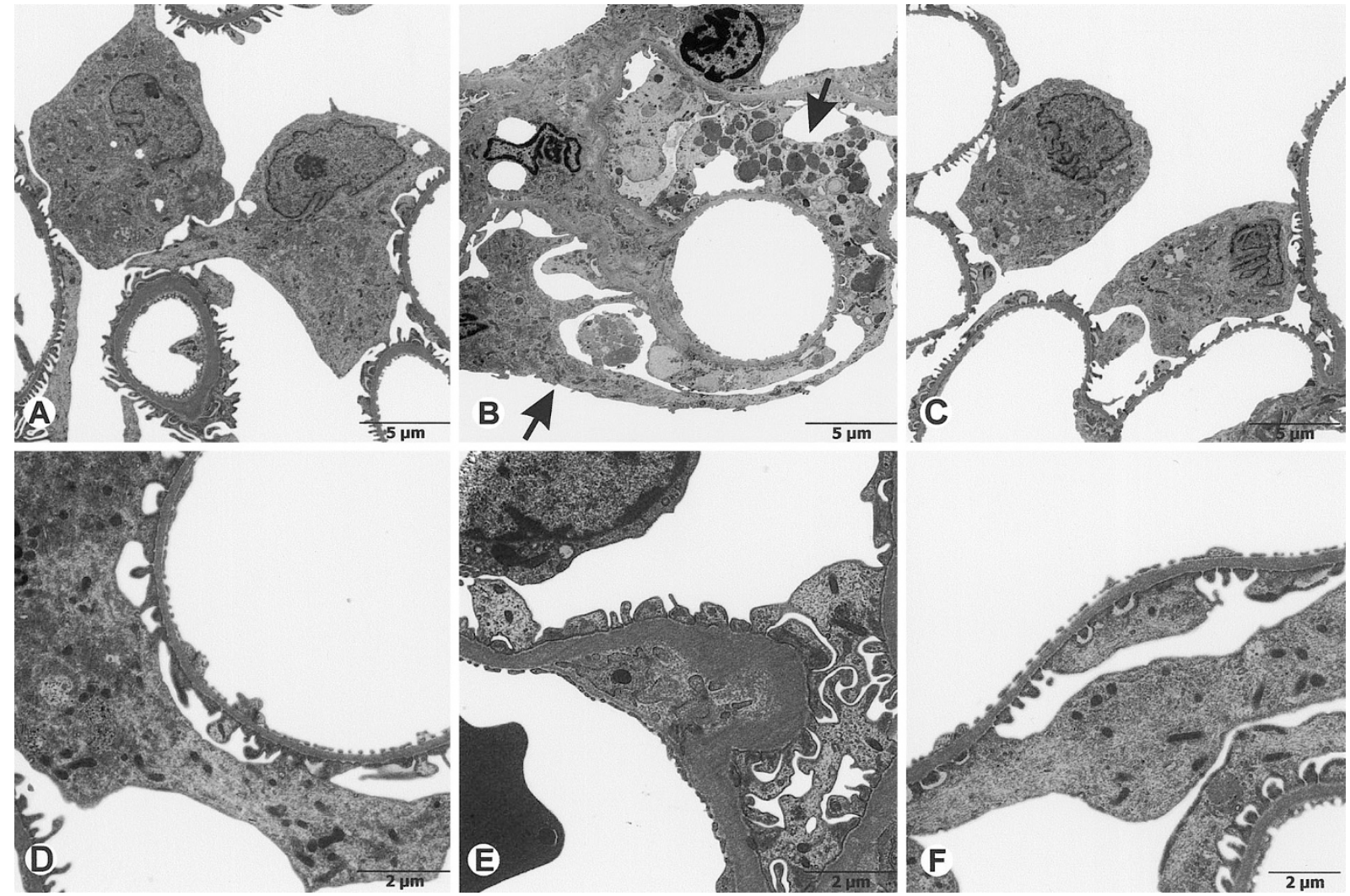

Figure 2.

A to C, Electron microscopy (1100:1). Podocyte hypertrophy (arrow) and degeneration with cystic transformation of the cytoplasm and loss of foot processes were seen in untreated diabetic rats (B). These changes were absent in diabetic rats that were treated with ACE-i (C) or lean controls (A). D to F, Electron microscopy (3000:1). Marked thickening of the glomerular basement membrane was seen in untreated diabetic animals (E) compared with nondiabetic controls (D) and ACE-i-treated animals (F).

animals, they significantly and comparably lowered the number of PCNA-positive podocytes. The number of PCNA-positive tubulointerstitial cells per view field was significantly higher in untreated diabetic compared with nondiabetic rats. Treatment with the ACE-i and $E T_{A}-R B$ showed no effect in nondiabetic rats, but in diabetic rats, ACE-i significantly prevented expres- sion of PCNA by tubulointerstitial cells, whereas $\mathrm{ET}_{\mathrm{A}}-\mathrm{RB}$ had no significant effect (Table 4, Figs. 3 to 5). ET-1.

ET-1 protein expression was higher in podocytes and mesangial cells of untreated diabetic compared with nondiabetic controls (Figs. 4B and 5). In diabetic rats, glomerular ET-1 expression was markedly lower 
Table 4. Number of PCNA-Positive Glomerular and Tubulointerstitial Cells

\begin{tabular}{|c|c|c|}
\hline Animal group & $\begin{array}{c}\text { PCNA + } \\
\text { cells/glomerular } \\
\text { profile }\end{array}$ & $\begin{array}{c}\text { PCNA }+ \text { cells/ } \\
\text { tubulointerstitial } \\
\text { area }\end{array}$ \\
\hline $\begin{array}{l}\text { Nondiabetic SHR/N-cp } \\
\quad(n=9)\end{array}$ & $1.78 \pm 0.89$ & $1.05 \pm 1.01$ \\
\hline $\begin{array}{l}\text { Nondiabetic SHR/N-cp } \\
\quad+\mathrm{ET}_{\mathrm{A}}-\mathrm{RB}(n=8)\end{array}$ & $2.11 \pm 0.16$ & $1.65 \pm 0.44$ \\
\hline $\begin{array}{l}\text { Nondiabetic SHR/N-cp } \\
\quad+\text { ACE-i }(n=13)\end{array}$ & $2.16 \pm 0.69$ & $0.97 \pm 0.27$ \\
\hline $\begin{array}{l}\text { Diabetic SHR/N-cp } \\
\quad(n=7)\end{array}$ & $4.88 \pm 1.74^{\star \dagger}$ & $4.12 \pm 1.06^{* \dagger}$ \\
\hline $\begin{array}{c}\text { Diabetic SHR/N-cp + } \\
\mathrm{ET}_{\mathrm{A}}-\mathrm{RB}(n=9)\end{array}$ & $2.67 \pm 1.21$ & $2.68 \pm 1.08^{*}$ \\
\hline $\begin{array}{c}\text { Diabetic SHR/N-cp }+ \\
\text { ACE-i }(n=12)\end{array}$ & $1.86 \pm 0.37$ & $0.45 \pm 0.19$ \\
\hline ANOVA & $p<0.05$ & $p<0.05$ \\
\hline
\end{tabular}

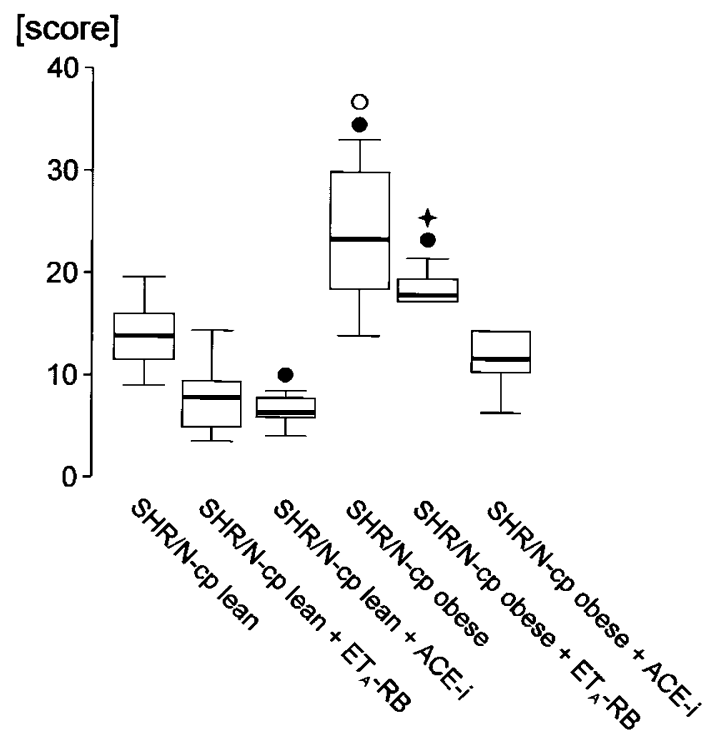

Figure 3.

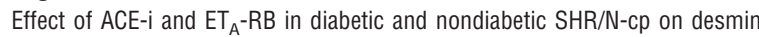
staining. $-p<0.05$ versus nondiabetic lean control; $\bigcirc, p<0.05$ untreated obese control versus obese diabetic SHR/N-cp + ACE-I; $\uparrow, p<0.05$ untreated obese control versus obese diabetic SHR/N-cp $+E_{A}-R B$. Desmin staining was marked in diabetic rats compared with nondiabetic animals. ACE-i only significantly reduced expression significantly.

after treatment with $A C E-i$, whereas $E_{A}-R B$ had no influence on glomerular ET-1 protein expression. Tubulointerstitial staining with ET-1 was significantly more pronounced in diabetic compared with nondiabetic rats. In diabetic rats, ET-1 protein expression was markedly lower after treatment with ACE-i, whereas $\mathrm{ET}_{\mathrm{A}}$-RB had no influence.

Fibronectin. Fibronectin staining of podocytes and mesangial cells was significantly higher in glomeruli of untreated diabetic compared with nondiabetic rats (Fig. 4A). In diabetic rats, ACE-i treatment but not $\mathrm{ET}_{\mathrm{A}}-\mathrm{RB}$ led to lower glomerular fibronectin expres- sion. Tubulointerstitial staining showed no difference between treated and untreated diabetic groups.

Platelet-Derived Growth Factor. Expression of platelet-derived growth factor (PDGF)-AB on the protein level was intense in podocytes, mesangial cells, and tubulointerstitial cells of untreated diabetic compared with nondiabetic rats ( Fig. 4C). In nondiabetic rats, interventions had no effect, whereas treatment with ACE-i but not with $\mathrm{ET}_{\mathrm{A}}-\mathrm{RB}$ in diabetic animals led to lower glomerular and tubulointerstitial staining for PDGF.

Transforming Growth Factor- $\beta_{1}$. Glomerular and tubulointerstitial expression of transforming growth factor- $\beta 1$ (TGF- $\beta 1$ ) was higher in diabetic compared with nondiabetic lean rats (Fig. 4D). Both treatments led to significantly lower expression compared with untreated diabetic rats, but only ACE-i completely normalized glomerular TGF- $\beta 1$ staining.

Desmin. Glomerular expression was only minor in podocytes of nondiabetic rats and was significantly higher in podocytes of untreated diabetic rats (Fig. 3), indicating podocyte damage. Desmin expression of podocytes was significantly lower after treatment with ACE-i but not with $\mathrm{ET}_{\mathrm{A}}-\mathrm{RB}$.

ET-1 and TGF- $\beta$ mRNA by Nonradioactive In Situ Hybridization. Glomerular and tubulointerstitial expression of ET-1 mRNA was significantly higher in untreated diabetic (glomerular, $1.23 \pm 0.35$; tubulointerstitial, $1.01 \pm 0.36$ ) compared with nondiabetic rats (glomerular, $1.16 \pm 0.56$; tubulointerstitial, $1.88 \pm$ 0.58). Treatment with ACE-i (glomerular, $0.97 \pm 0.23$; tubulointerstitial, $1.34 \pm 0.46$ ) but not with $\mathrm{ET}_{\mathrm{A}}-\mathrm{RB}$ (glomerular, $1.44 \pm 0.37$; tubulointerstitial, $2.12 \pm$ 0.17 ) in diabetic animals led to significantly lower expression. TGF- $\beta$ expression was more marked in glomerular and tubulointerstitial cells of diabetic rats (glomerular, $0.97 \pm 0.23$; tubulointerstitial, $1.86 \pm$ 0.46 ) than in nondiabetic controls (glomerular, $0.42 \pm$ 0.1 ; tubulointerstitial, $0.59 \pm 0.36$ ). There was no significant difference in treated nondiabetic rats, whereas in diabetic rats, ACE-i (glomerular, $1.04 \pm$ 0.28 ; tubulointerstitial, $1.13 \pm 0.45$ ) and $\mathrm{ET}_{\mathrm{A}}-\mathrm{RB}$ (glomerular, $0.72 \pm 0.44$; tubulointerstitial, $1.34 \pm 0.45$ ) treatment led to lower glomerular and tubulointerstitial staining.

Reverse Transcription-PCR for TGF- $\beta$ mRNA. TGF- $\beta 1$ mRNA was significantly increased in untreated diabetic rats $(1.78 \pm 0.69)$ compared with nondiabetic untreated rats $(0.98 \pm 0.23)$. In nondiabetic animals, interventions caused no significant change, but in diabetic rats, TGF- $\beta 1$ mRNA expression was significantly lower in both intervention groups (diabetes $+\mathrm{ET}_{\mathrm{A}}-\mathrm{RB}, 1.20 \pm 0.5$; diabetes + ACE-i, $1.12 \pm 0.3)$.

\section{Discussion}

A number of type 2 diabetic models have recently been described, such as ob/ob and db/db mice (Halseth et al, 2002), KK-Ay mice (Miura et al, 2002), Nagoya-Shibata-Yasuda mice (Hamada et al, 2001), OLETF rats (Jesmin et al, 2002), ZDF-obese diabetic 

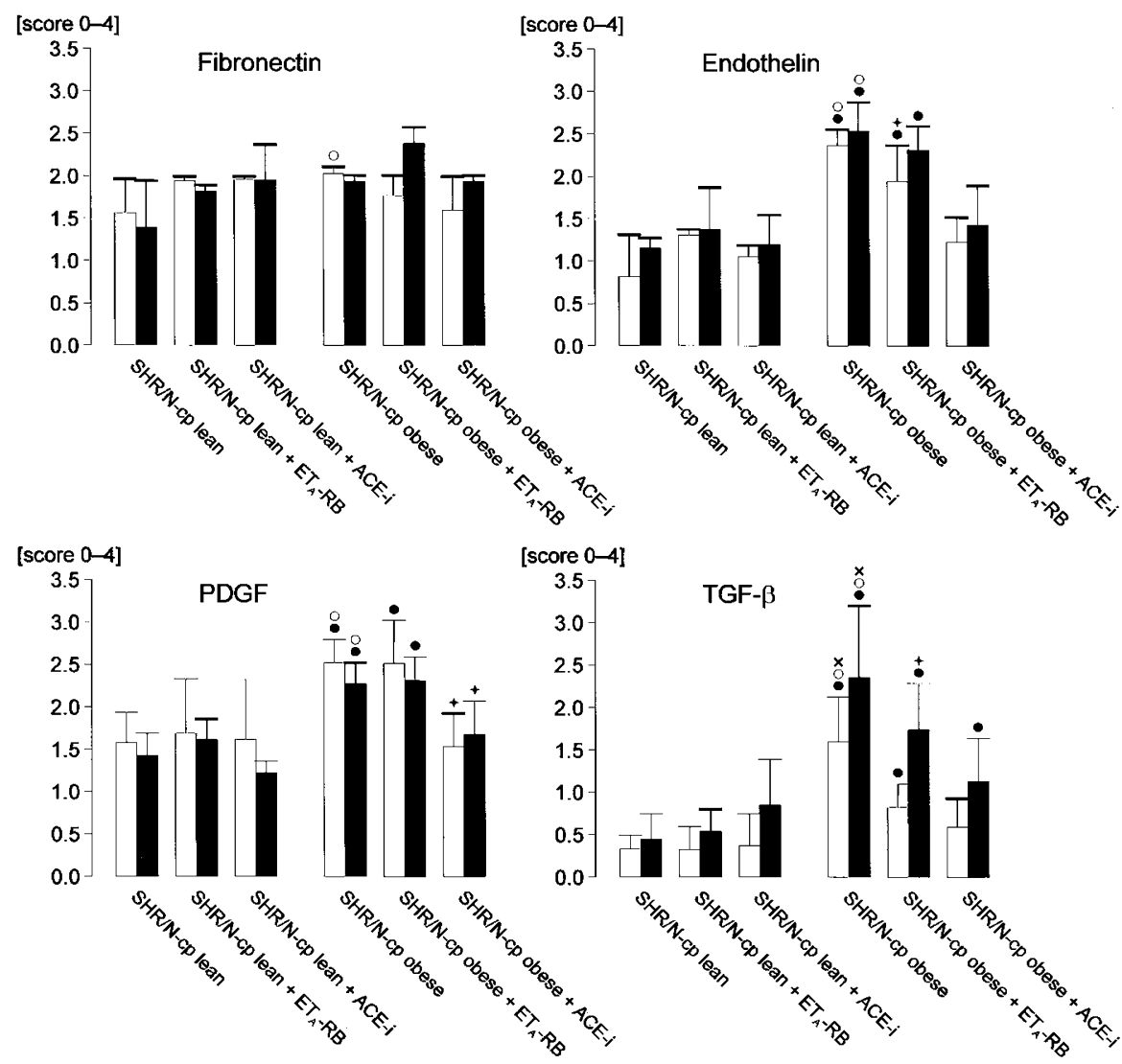

Figure 4.

Effect of ACE-i and $\mathrm{ET}_{\mathrm{A}}-\mathrm{RB}$ on glomerular and tubulointerstitial expression of fibronectin, endothelin, platelet-derived growth factor (PDGF), and transforming growth factor- $\beta$ (TGF- $\beta$ ) in diabetic and nondiabetic SHR/N-cp. $\square$, glomerular expression; $\square$, tubulointerstitial expression; $\bullet, p<0.05$ versus nondiabetic lean control; $O$, $p<0.05$ untreated obese control versus obese diabetic SHR/N-cp + ACE-i. $\times, p<0.05$ untreated obese control versus obese diabetic SHR/N-cp + ET $-\mathrm{RB} ; \uparrow$ $p<0.05$ obese diabetic SHR/N-cp + ACE-i versus obese diabetic SHR/N-cp $+\mathrm{ET}_{\mathrm{A}}-\mathrm{RB}$. Fibronectin: In diabetic SHR/N-cp rats, ACE-i only decreased glomerular fibronectin expression. ET-1: In diabetic SHR/N-cp rats, expression was markedly lower after treatment with ACE-i. Tubulointerstitial staining with ET-1 was significantly higher in diabetic rats than in nondiabetic controls. In diabetic rats, expression was markedly lower after treatment with ACE-i. PDGF: ACE-i treatment reduced glomerular and tubulointerstitial staining in obese animals. TGF- $\beta_{1}$ : Both treatment groups showed significantly lower glomerular and tubulointerstitial TGF- $\beta 1$ protein expression than untreated diabetic rats, but ACE-i only normalized glomerular staining.

rats (Coopey et al, 2002), and GK rats (Phillips et al, 2001), all of them with advantages and disadvantages. The SHR/N-cp is a model resembling type 2 diabetes of humans to the extent that it exhibits marked diffuse glomerulosclerosis and occasionally suggestive nodules as well as marked tubulointerstitial lesions, which are much more pronounced than in other type 2 mouse or rat models and are comparable to human diabetic renal disease. The suggestive nodules differ from intercapillary glomerulosclerosis originally described by Kimmelstiel and Wilson (1936): They are cellular with nuclei present throughout the lesion (Velasquez et al, 1989). The number of mesangial cells of Kimmelstiel-Wilson glomerulosclerosis varies (Zollinger and Mihatsch, 1978), but they are conspicuous early in the disease (Katz et al, 2002).

We had been struck by the marked expression of ET-1 in the glomeruli of the SHR/N-cp diabetic rats, and this led to the hypothesis that blockade of this effector system might have an impact on the development of glomerular lesions. All types of glomerular cells express $\mathrm{ET}_{\mathrm{A}}$ and/or $\mathrm{ET}_{\mathrm{B}}$ receptors (Hargrove et al, 2000), but little is known about the pathogenetic role of ET-1, and the few results that had been obtained so far remain controversial (Benigni et al, 1998; Dhein et al, 2000; Hocher et al, 1998; Kelly et al, 2000). We assessed the effect of the $\mathrm{ET}_{\mathrm{A}}$ receptorspecific antagonist LU135252 in diabetic and nondiabetic SHR/N-cp and compared it with the well defined renoprotective action of an ACE-i on renal structure (Cordonnier et al, 2001).

In the normotensive Goto Kakizaki model (Phillips et al, 2001), hyperglycemia causes basal membrane thickening but no albuminuria or progressive glomerulosclerosis. Superimposition of DOCA salt hypertension causes both albuminuria and glomerular lesions (personal communication, Prof. J. Floege, University of Aachen, Aachen, Germany). It is therefore probable that the marked glomerular and tubulointerstitial lesions in the hypertensive SHR/N-cp model are the combined result of hyperglycemia and hypertension, leading to pronounced alterations of glomerular and tubulointerstitial structures. $\mathrm{ET}_{\mathrm{A}}-\mathrm{RB}$ reduced blood pressure in models of renal damage (Remuzzi and Bertani, 1998), presumably in part as the result of increased expression of the vasodilator nitric oxide 

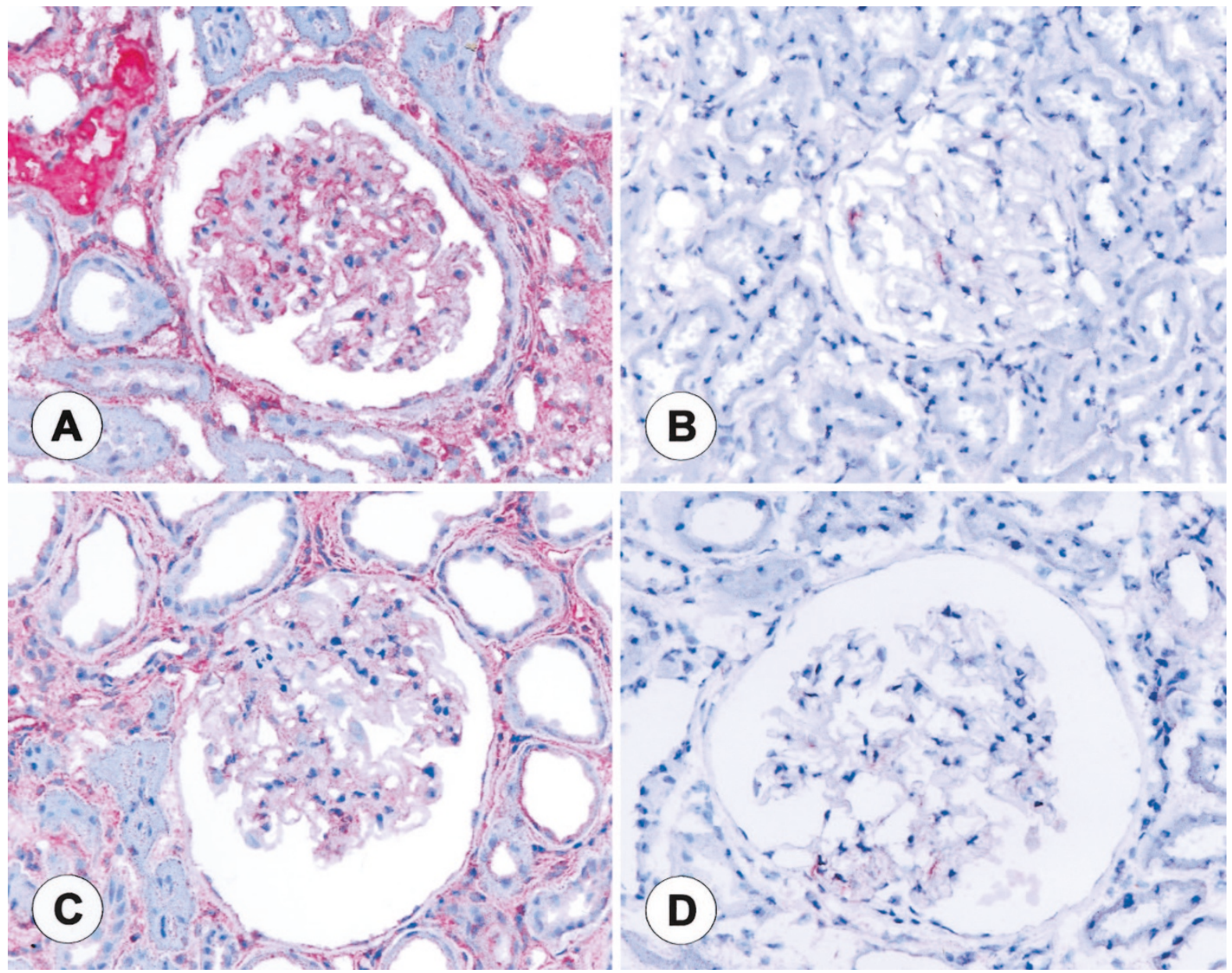

\section{Figure 5.}

Effect of $A C E-i$ and $\mathrm{ET}_{\mathrm{A}}-\mathrm{RB}$ on endothelin protein expression of glomerular cells (immunohistochemistry, magnification, 1:300). A, Marked staining of glomerular cells in untreated diabetic obese animal. B, No staining in nondiabetic untreated lean animal. $\mathrm{C}_{,} \mathrm{ET}_{\mathrm{A}}-\mathrm{RB}_{\mathrm{B}}$ treatment in obese diabetic rats still led to marked staining of glomerular cells. D, Only very little staining in glomerular cells of ACE-i-treated obese diabetic rats.

(Verhaar et al, 1998). In rats with streptozotocin diabetes, Benigni et al (1998) showed that nonselective ET-1 blockade normalizes systemic blood pressure and causes striking amelioration of renal lesions. In contrast, Kelly et al (2000) studied diabetic transgenic mREN-2-27 rats with marked activation of the renin angiotensin system and found no benefit from $E T_{A}-R B$ treatment on renal pathology despite lowering of blood pressure. In the present study, the $E_{A}-R B$ failed to reduce blood pressure but nevertheless improved renal lesions, possibly via direct effects on renal structure.

Glomerular volume was only slightly increased in the $\mathrm{SHR} / \mathrm{N}-\mathrm{cp}$ than in nondiabetic rats; this finding is of note because conflicting results have been observed in humans. In patients with type 2 diabetes, Østerby (1993) and Bilous et al (1989) had found higher glomerular volumes, but this was not consistently found in elderly hypertensive individuals (Ellis and Cairns, 2001). Although the reason for this is not yet clear, a confounding effect of hypertension, however, could be excluded in the present model.

The present study confirms previous observations in rats with insulinopenic diabetes that $E T_{A}-R B$ re- duced glomerulosclerosis (Benigni et al, 1998). The result was confirmed by measuring capillary length density, which is an extremely sensitive index of glomerulosclerosis. The effect of $E T_{A}-R B$ is particularly remarkable, because - in contrast to ACE-I-the $E T_{A}-R B$ has failed to reduce mean glomerular volume and blood pressure (by tail plethysmography). The changes in glomerular cells are also of interest: As in other models of renal damage (Gassler et al, 2001; Pagtalunan et al, 1997), we confirmed podocyte damage and subsequent loss in this model of type 2 diabetes. Podocyte damage was documented by de novo expression of desmin as a sensitive marker of podocyte injury (Phillips et al, 2001). Increased numbers of podocytes per glomerulus stained positive for PCNA. This finding may indicate cell activation rather than cell proliferation, however. The latter possibility is unlikely in view of fact that podocytes are postmitotic cells (Kriz et al, 1996). Although podocytes express ET receptors, $E T_{A}-R B$ failed to normalize podocyte number and volume. This finding contrasted with the effects of the ACE-i.

Of particular interest in this context are mesangial cells, because in rat (Takeda et al, 1992) and human 
(Goruppi et al, 2002; Orth et al, 2000) mesangial cell cultures, ET-1 is a potent stimulator of mesangial cell proliferation. In diabetic SHR/N-cp animals, glomerular ET-1 protein expression was also increased. Nevertheless, the number of mesangial cells was not different in diabetic and nondiabetic animals and $\mathrm{ET}_{\mathrm{A}}-\mathrm{RB}$ had no effect on mesangial cell number. In contrast to $\mathrm{ET}_{\mathrm{A}}-\mathrm{RBn}$ ACE-i lowered mesangial cell number, maybe as an effect of reduced glomerular TGF- $\beta 1$ and PDGF protein expression.

Recently, endothelial cells have attracted considerable interest. In a model of progressive glomerulonephritis, the number of endothelial cells and the length of capillaries increased initially, indicating proliferation, but such increase was not sustained and was followed by progressive loss of endothelial cells via apoptosis (Kang et al, 2001; Shimizu et al, 1997). The present observation is in line with these findings of low endothelial cell number and increased endothelial cell volume in chronic glomerulonephritis (Shimizu et al, 1998). Administration of $E_{A}-R B$ was associated with lower endothelial cell volume and with higher numbers of endothelial cells, as was seen after administration of ACE-i. One could speculate that this finding is the result of less apoptosis and cellular stress after inhibition of the RAS.

Many arguments have been provided that ET-1 may play a role in the genesis of tubulointerstitial lesions in renal damage models. In the damaged kidney, interstitial cells express ET-1 (Remuzzi and Bertani, 1998). This observation led to the idea that ET-1 plays a causal role in the genesis of interstitial fibrosis (Benigni et al, 1998). The expression of ET-1 on the protein level was markedly increased in the present type 2 diabetes model, yet $\mathrm{ET}_{\mathrm{A}}$-RB failed to decrease $\mathrm{ET}-1$ protein expression and tubulointerstitial damage, in contrast to ACE-I, which interfered with both. This finding is remarkable because expression of TGF- $\beta$, which is known to stimulate tubulointerstitial fibrosis (Basile, 2001; Chen et al, 2001), was decreased by both interventions, yet $\mathrm{ET}_{\mathrm{A}}$-RB did not reduce tubulointerstitial fibrosis. This may be due to redundancy of systems, because anti-TGF- $\beta$ therapy alone had also failed to influence albuminuria in $\mathrm{db} / \mathrm{db}$ mice (Basile, 2001). The data suggest that angiotensin II plays a more pathogenetic role in comparison to ET-1 and exclude the hypothesis that elevation of angiotensin II is mediated via ET-1.

\section{Conclusion}

From the above observations, we conclude that the SHR/N-cp model demonstrates marked glomerular and tubulointerstitial lesions, which make it an interesting tool for pathomechanistic studies of type 2 diabetes. Despite marked expression of ET-1 and ET receptors, $\mathrm{ET}_{\mathrm{A}}$ blockade was far less effective than ACE inhibition in attenuating glomerular and tubulointerstitial lesions.

\section{Materials and Methods}

\section{Animals}

The SHR/N-cp rat is a model of non-insulindependent diabetes, which resembles human type 2 diabetes (Tulp and Weng, 1992). This strain was generated by mating obese Koletzky rats and hypertensive SHR rats. The resultant progeny are either lean or obese. Hypertension in male animals disappears when obesity develops. The diabetic SHR/N-cp inherits obesity as an autosomal recessive trait. Because corpulent rats do not reproduce, the rats are bred by mating of heterozygous animals. Mating yields three genotypes but only two phenotypes, ie, the homozygous (cp/cp) corpulent and the heterozygous $(\mathrm{cp} /+)$ and homozygous $(+/+)$ lean rats, in a ratio of $1: 2: 1$. The development of obesity is linked to reduced metabolic expenditure of energy (Marette et al, 1991; Tulp, 1991). Obese rats have hypertriglyceridemia and hyperinsulinemia. Lean rats have increased insulin levels, but only some animals develop hyperglycemia (Tulp and Weng, 1992) (Table 1).

For the present study, 6-month-old male SHR/N-cp obese rats and their age-matched lean controls were obtained from Vasarr (New York, New York) and were housed at standard light cycle (light 08:00 am to 8:00 pm daily), $40 \%$ to $70 \%$ relative humidity, and maintained at $22 \pm 1^{\circ} \mathrm{C}$ in standard box cages. All animals were allowed free access to Standard Purina Chow (\#5012, Purina Mills, St. Louis, Missouri) and water throughout the studies.

\section{Experimental Protocol}

The animals were randomly allotted to the following six experimental groups:

1. SHR/N-cp lean untreated control $(n=9)$

2. SHR/N-cp lean $+E_{A^{-}}$RB LU135252 $(50 \mathrm{mg} / \mathrm{kg}$ bw, $n=8$ )

3. SHR/N-cp lean + ACE-i Trandolapril $(0.3 \mathrm{mg} / \mathrm{kg}$ bw, $n=13$ )

4. SHR/N-cp obese untreated control $(n=7)$

5. SHR/N-cp obese + ET $_{\text {A }}$ RB LU135252 $(50 \mathrm{mg} / \mathrm{kg}$ bw, $n=9$ )

6. SHR/N-cp obese + ACE-i Trandolapril (0.3 mg/kg bw, $n=12$ )

The drugs were administered in the drinking fluid at concentrations calculated to deliver the abovementioned doses. Daily food and water consumption was monitored, and the doses were adjusted. Body weight, blood glucose, and blood pressure (by tail plethysmography) were measured at regular intervals. After 6 months, animals were kept in metabolic cages for 1 day to collect 24-hour urine. Urinary albumin excretion was measured using a rat-specific sandwich ELISA system as described in detail elsewhere (Schwarz et al, 1998). The experiment was terminated after 6 months by retrograde aortic perfusion. 


\section{Tissue Preparation}

One kidney was taken out after perfusion with Rheomacrodex and ice-cold $\mathrm{NaCl}$ for immunohistologic and in situ investigations; the other organs were taken out after continuing perfusion with glutaraldehyde for morphometric investigations. The second glutaraldehyde-perfused kidney was dissected in a plane perpendicular to the interpolar axis, yielding slices of 1 $\mathrm{mm}$ width. Ten small pieces of this kidney were selected by area weighted sampling for embedding in Epon-Araldite. Semithin $(1 \mu \mathrm{m})$ and ultrathin sections $(0.08 \mu \mathrm{m})$ were prepared and stained with methylene blue/basic fuchsin or lead citrate/uranyl acetate, respectively. The remaining tissue slices were embedded in paraffin; 4- $\mu \mathrm{m}$ sections were prepared and stained with hematoxylin/eosin (HE) and periodic acidSchiff (PAS). For immunohistologic investigations, one half of the $\mathrm{NaCl}$-perfused kidney was fixed in $4 \%$ buffered formaldehyde, embedded in paraffin, and cut into $2-\mu \mathrm{m}$-thick sections. For in situ hybridization, the other half of the kidney was snap-frozen in liquid nitrogen-cooled isopentane. Paraffin sections were prepared and were reacted with antibodies using the avidin biotin method (Amann et al, 1998; Schwarz et al, 1998; Wolf et al, 1999): PCNA ( $\alpha$-PCNA monoclonal mouse; Immunotech, Marseille, France; 1:150), TGF- $\beta_{1}$ (anti-TGF- $\beta_{1}$, rabbit polyclonal IgG; Santa Cruz Biotechnology, Santa Cruz, California; 1:300), fibronectin ( $\alpha$-fibronectin polyclonal rabbit; SigmaAldrich Chemie $\mathrm{GmbH}$, Steinheim, Germany; 1:10), and desmin ( $\alpha$-desmin monoclonal mouse; DAKO, Hamburg, Germany; 1:400). Five-micrometer cryostat sections were prepared and were reacted with antibodies using the avidin biotin method: PDGF-AB ( $\alpha$-PDGF-AB polyclonal goat; Upstate Biotechnology Inc., Waltham, Massachusetts; 1:50) and endothelin ( $\alpha$-ET-1 polyclonal rabbit; Biotrend, Cologne, Germany; 1:20).

\section{Morphologic Investigations}

Indices of Renal Damage (Glomerulosclerosis, Tubulointerstitial, and Vascular Damage). The degree of sclerosis within the glomerular tuft as an index of progression was determined on PAS-stained paraffin sections adopting the semiquantitative scoring system proposed by El Nahas et al (1991). With the use of light microscopy at a magnification of $\times 400$, the glomerular score of each animal was derived as the mean of 100 glomeruli. The severity of glomerulosclerosis was expressed on an arbitrary scale from 0 to 4 as described elsewhere (El Nahas et al, 1991; Ghandi et al, 1998).

Tubulointerstitial (TBI) and vascular damage (VDI) were assessed on PAS-stained paraffin sections at a magnification of $\times 100$ using a similar scoring systems with scores 0 to 4 (Veniant et al, 1994).

Glomerular Geometry. Area $\left(\mathrm{A}_{\mathrm{A}}\right)$ and volume density $\left(V_{V}\right)$ of the renal cortex and medulla as well as the number of glomeruli per area $\left(\mathrm{N}_{\mathrm{A}}\right)$ were measured using a Zeiss eyepiece (Integrationsplatte II; Zeiss
Company, Oberkochen, Germany) and the pointcounting method $\left(P_{P}=A_{A}=V_{V}\right)$ at a magnification of $\times 400$ as described in detail previously (Amann et al, 2001; Weibel, 1997).

Analysis of Glomerular Capillaries and Cellularity on Semithin Sections. On five semithin sections per animal, glomerular capillaries and cellularity were analyzed using the point-counting method and a 100point eyepiece (Integrationsplatte II) at a magnification of 1000 (oil immersion) as previously described (Amann et al, 2001). Briefly, the length density $\left(L_{v}\right)$ of glomerular capillaries was determined according to the standard stereologic formula $L_{V}=2 Q_{A}$ (with $Q_{A}$ being the number of capillary transects per area of the capillary tuft). Glomerular cellularity (podocytes, mesangial cells, and endothelial cells) was assessed by stereologic techniques in at least 30 glomeruli per animal from cell density per volume $\left(\mathrm{Nc}_{\mathrm{v}}\right)$ and volume density of the cell type $\left(\mathrm{V}_{\mathrm{v}}\right)$ according to the equation $\mathrm{Ncv}=\mathrm{k} / \beta \times \mathrm{Nc}_{\mathrm{A}}{ }^{1.5} / \mathrm{Nc}_{\mathrm{v}}{ }^{0.5}$ with $\beta$ for podocytes $=1.5$ and for mesangial and endothelial cells $=1.4$ and $\mathrm{k}=$ 1 (Amann et al, 1996). The respective cell volume was calculated with $\mathrm{V}_{\mathrm{c}}=\mathrm{V}_{\mathrm{v}} \times \mathrm{V}_{\text {glom }}$.

Electron Microscopy. In several randomly selected animals per group, ultrathin sections of the renal cortex were qualitatively investigated using a Zeiss EM 10 eyepiece (Integrationsplatte II) at various magnifications.

Immunohistologic Investigations. PCNA immunohistochemistry was examined using light microscopy at a magnification of $\times 400$. In 50 glomeruli per kidney, the number of PCNA-positive cells per glomerulus as well as per glomerular and per tubulointerstitial area was counted.

Immunohistologic stains using antibodies against TGF- $\beta_{1}$, ET-1, fibronectin, and PDGF were analyzed by two investigators who were masked to the animal group; scoring was performed as described in detail previously (Amann et al, 1998). In $n=5$ animals per group, desmin positivity of podocytes was investigated as a marker of cell degeneration. For analysis of desmin immunohistochemistry, the capillary tuft was divided into four quarters and the following scoring system was used by two investigators who were masked to the animal group: score 0 , no expression; score 1, desmin-positive cells in one quarter; score 2, desmin-positive cells in two quarters; score 3 , desmin-positive cells in three quarters; and score 4, desmin-positive cells all over the capillary tuft. The damage score was then calculated as follows: $\{(0-$ score 0$)+$ score $1+$ score 2 + score $3+$ score 4]:5 $\}+15$.

In Situ Hybridization. Nonradioactive in situ hybridization using ET-1 and TGF- $\beta$ sense and antisense probes was performed in five animals per group as described in detail previously (Amann et al, 2000).

\section{Statistics}

Data are given as mean \pm SD. After testing for normal distribution, the Kruskal-Wallis test or one-way ANOVA was chosen for ANOVA, followed by Duncan's 
multiple-range test to test for differences between groups. The results were considered significant at $p<$ 0.05 .

\section{Acknowledgements}

M.L. Gro $\beta$ was recipient of a grant in the Graduiertenkolleg "Nieren- und Kreislaufregulation" of the Deutsche Forschungsgemeinschaft (DFG). Parts of the study were supported by grants of the University of Heidelberg (Juniorprojects No 83/97 and 133/00) and the Deutsche Forschungsgemeinschaft (SFB 423, project B8). The skillful technical assistance of $H$. Ziebart, Z. Antoni, H. Derks, G. Gorsberg, M. Klewer, P. Rieger, S. Söllner, and M. Weckbach is gratefully acknowledged. The authors thank Dr. A. Kuhlmann, Department of Pathology, University of ErlangenNürnberg for desmin immunohistology and Dr. S. Orth, Dialyzezentrum Schwandorf, for helping with some of the animals. The help of U. Reulbach, Department of Biostatistics, University of ErlangenNürnberg, with the statistics and $H$. Derks and $U$. Burkhardt with the layout is also acknowledged.

\section{References}

Amann K, Koch A, Hofstetter J, Gross ML, Haas C, Orth SR, Ehmke H, Rump LC, and Ritz E (2001). Glomerulosclerosis and progression: Effect of subantihypertensive doses of $\alpha$ and $\beta$-blockers. Kidney Int 60:1309-1323.

Amann K, Kronenberg G, Gehlen F, Wessels S, Orth S, Muenter K, Ehmke H, Mall G, and Ritz E (1998). Cardiac remodelling in experimental renal failure-An immunohistochemical study. Nephrol Dial Transplant 13:1958-1966.

Amann K, Münter K, Wagner J, Balajew V, Nabokov A, Hergenröder S, Mall G, and Ritz E (2000). Endothelin A receptor blockade prevents capillary/myocyte mismatch in the heart of uremic animals. J Am Soc Nephrol 11:16911699.

Amann K, Nichols C, Toernig J, Schwarz U, Zeier M, Mall G, and Ritz E (1996). Effect of ramipril, nifedipine, and moxonidine on glomerular morphology and podocyte structure in experimental renal failure. Nephrol Dial Transplant 11:10031011.

Basile DP (2001). Transforming growth factor- $\beta$ as a target for treatment in diabetic nephropathy. Am $\mathrm{J}$ Kidney Dis 34:887-892.

Benigni A, Colosio V, Brena C, Bruzzi I, Bertani T, and Remuzzi G (1998). Unselective inhibition of endothelin receptors reduces renal dysfunction in experimental diabetes. Diabetes 47:450-456.

Bilous RW, Mauer SM, Sutherland DE, and Steffes MW (1989). Mean glomerular volume and rate of development of diabetic nephropathy. Diabetes 38:1142-1147.

Chen S, Hong SW, Iglesias de la Cruz MC, Isono M, Casaretto A, and Ziyadeh FN (2001). The key role of the transforming growth factor- $\beta$ system in the pathogenesis of diabetic nephropathy. Ren Fail 23:471-481.

Coopey LJ, Gellett JS, Davidson EP, Dunlap JA, and Yorek M (2002). Changes in endoneurial blood flow, motor nerve conduction velocity and vascular relaxation of epineurial arterioles of the sciatic nerve in ZDF-obese diabetic rats. Diabetes Metab Res Rev 18:49-56.

Cordonnier DJ, Zaoui P, and Halimi S (2001). Role of ACE inhibitors in patients with diabetes mellitus. Drugs 61:18831892.

Dhein S, Hochreuther S, aus dem Spring C, Bollig K, Hufnagel C, and Raschak M (2000). Long-term effects of the endothelin A receptor antagonist LU135252 and the angiotensin-converting enzyme inhibitor Trandolapril on diabetic angiopathy and nephropathy in a chronic type I diabetes mellitus rat model. J Pharmacol Exp Ther 293:351-359.

Ellis PA and Cairns HS (2001). Renal impairment in elderly patients with hypertension and diabetes. QJM 94:261-265.

El Nahas AM, Bassett AH, Cope GH, and Carpentier JE (1991). Role of growth hormone in the development of experimental renal scarring. Kidney Int 40:29-34.

Gassler N, Elger M, Kranzlin B, Kriz W, Gretz N, Hahnel B, Hosser H, and Hartmann I (2001). Podocyte injury underlies the progression of focal segmental glomerulosclerosis in the fa/fa Zucker. Kidney Int 60:106-116.

Ghandi M, Olson JL, and Meyer TW (1998). Contribution of tubular injury to loss of remnant kidney function. Kidney Int 54:1157-1165.

Goruppi S, Bonventre JV, and Kyriakis JM (2002). Signaling pathways and late-onset gene induction associated with renal mesangial cell hypertrophy. EMBO J 21:5427-5436.

Halseth AE, Ensor NJ, White TA, Ross SA, and Gulve EA (2002). Acute and chronic treatment of ob/ob and db/db mice with AICAR decreases blood glucose concentrations. Biochem Biophys Res Commun 21:798-805.

Hamada Y, Ikegami H, Meda H, Kawaguchi K, Yamada K, Babaya N, Shibata M, and Ogihara T (2001). Insulin secretion to glucose as well as non glucose stimuli is impaired in spontaneously diabetic Nagoya-Shibsata-Yasuda mice. Metabolism 50:1282-1285.

Hargrove GM, Dufresne J, Whiteside C, Muruve DA, and Wong NC (2000). Diabetes mellitus increases endothelin-1 gene transcription in rat kidney. Kidney Int 58:1534-1545.

Hocher B, Lun A, Priem F, Neumayer HH, and Raschak M (1998). Renal endothelin system on diabetes: Comparison of angiotensin-converting enzyme inhibition and endothelin-A antagonism. J Cardiovasc Pharmacol 31(Suppl 1):492-495.

Hori S, Komatsu Y, Shigemoto R, Mizuno N, and Nakanishi S (1992). Distinct tissue distribution and cellular localisation of two messenger ribonucleic acids encoding different subtypes of rat endothelin receptors. Endocrinology 130:18851895.

Jesmin S, Sakuma I, Hattori Y, Fujii S, and Kitabatake A (2002). Long-acting channel blocker benidipine suppresses expression of angiogenic growth factors and prevents cardiac remodelling in a type II diabetic rat model. Diabetologia 45:402-415.

Kang DH, Anderson S, Kim YG, Mazzali M, Suga S, Jefferson JA, Gordon KL, Oyama TT, Hughes J, Hugo C, Kerjaschki D, Schreiner GF, and Johnson RJ (2001). Impaired angiogenesis in the aging kidney: Potential role of VEGF and TSP-1 in renal disease. Am J Kidney Dis 37:601-611. 
Katz A, Caramori MLA, Sisson-Ross S, Groppoli T, Basgen $\mathrm{JM}$, and Mauer M (2002). An increase in the cell component of the cortical interstitium antedates interstitial fibrosis in type 1 diabetic patients. Kidney Int 61:2058-2066.

Kelly DJ, Skinner SL, Gilbert RE, Cox AJ, Cooper ME, and Wilkinson-Berka JL (2000). Effects of endothelin or angiotensin II receptor blockade on diabetes in the transgenic (mRen-2) 27 rat. Kidney Int 57:1882-1894.

Kimmelstiel P and Wilson P (1936). Intercapillary lesions in glomeruli of kidney. Am J Pathol 12:83-105.

Kriz W, Kretzler M, Nagata M, Provoost AP, Shirato I, Uiker S, Sakai T, and Lemley KV (1996). A frequent pathway to glomerulosclerosis: Tuft architecture-podocyte damagesegmental sclerosis. Kidney Blood Press Res 19:245-253.

Marette A, Tulp O, and Bukowieki LJ (1991). Mechanism linking insulin resistance to defective thermogenesis in brown adipose tissue of genetically obese rats. Int $\mathrm{J}$ Obes 15:823831.

Marsen T, Schramek H, and Dunn MJ (1994). Renal actions of endothelin: Linking cellular signaling pathways to kidney disease. Kidney Int 45:336-344.

Miura T, Furuta K, Yasuda A, Iwamoto N, Kato M, Ishiha E, Ishida T, and Tanigawa K (2002). Anti-diabetic effect of nitobegiku in KK-Ay diabetic mice. Am J Chin Med 30:81-86.

Orth SR, Amann K, Gehlen F, Unger L, Wagner J, Raschak M, and Ritz E (2000). Adult human mesangial cells (HMCs) express endothelin-B-receptors which mediate endothelin-1 induced cell growth. J Cardiovasc Pharmacol 36(5 Suppl 1):S232-S248.

Østerby R (1993). Renal pathology in diabetes mellitus. Curr Opin Nephrol Hypertens 2:465-483.

Pagtalunan ME, Miller PL, Jumping-Eagle S, Nelson RG, Myers BD, Rennke HG, Coplon NS, Sun L, and Meyer TW (1997). Podocyte loss and progressive glomerular injury in type 2 diabetes. J Clin Invest 15:342-348.

Phillips AO, Babooal K, Riley S, Groene H, Janssen U, Steadman R, Williams J, and Floege J (2001). Association of prolonged hyperglycemia with glomerular hypertrophy and renal basement membrane thickening in the Goto-Kakizaki model of non-insulin-dependent diabetes mellitus. Am J Kidney Dis 37:400-410.

Rebibou JM, He CJ, Delarue F, Peraldi MN, Adida C, Rondeau E, and Sraer JD (1992). Functional endothelin 1 receptors on human glomerular podocytes and mesangial cells. Nephrol Dial Transplant 7:288-292.

Remuzzi G and Bertani T (1998). Pathophysiology of Progressive nephropathies. N Engl J Med 339:1448-1456.

Schwarz U, Amann K, Orth S, Simonaviciene A, Wessels S, and Ritz E (1998). Effect of $1,25(\mathrm{OH})_{2}$ vitamin D3 on glomerulosclerosis in subtotally nephrectomized rats. Kidney Int 53:1696-1705.
Shimizu A, Kitamura H, Mascua Y, Ishizaki M, Sugisaki Y, and Yamanka N (1997). Rare glomerular capillary regeneration and subsequent capillary regression with endothelial cell apoptosis in progressive glomerulonephritis. Am J Pathol 151:1231-1239.

Shimizu A, Masuda $\mathrm{Y}$, Kitamura $\mathrm{H}$, Sugisaki $\mathrm{Y}$, and Vamanaka N (1998). Recovery of damaged glomerular capillary network with endothelial cell apoptosis in experimental proliferative glomerulonephritis. Nephron 79:206-214.

Takeda M, Breyer MD, Noland TD, Homma T, Hoover RL, Inagami T, and Kon V (1992). Endothelin-1 receptor antagonist: Effects on endothelin- and cyclosporine-treated mesangial cells. Kidney Int 41:1713-1719.

Tulp O (1991). Thermogenesis and obesity in the LA/N-cp and SHR/N-cp rat strains. In: Hansen CT, Michaelis OE IV, editors. New models of genetically obese rats for studies in diabetes, heart disease and complication of obesity. Bethesda, MD: Veterinary Resources Branch, National Institutes of Health, 17-25.

Tulp O and Weng M (1992). Effect of genetic dilution on development of diabetes, impaired glucose tolerance and in vitro glucose tolerance and in vitro glucose oxidation in $\mathrm{La} / \mathrm{N}-\mathrm{cp} \times \mathrm{SHR} / \mathrm{N}-\mathrm{cp} \mathrm{F} 1$ hybrid rats. Comp Biochem Physiol 101:403-408.

Velasquez MT, Kimmel PL, Miachaelis IV OE, Carswell N, Abraham A, and Bosch JP (1989). Effect of carbohydrate intake on kidney function and structure in SHR/N-cp rats. A new model of NIDDM. Diabetes 38:679-685.

Veniant M, Heudes D, Clozel JP, Bruneval P, and Menard J (1994). Calcium blockade versus ACE inhibition in clipped and unclipped kidneys of 2K-1C rats. Kidney Int 46:421-429.

Verhaar MC, Strachan FE, Newby DE, Cruden NL, Koomans HA, Rabelink TJ, and Webb DJ (1998). Blockade of endothelin $A(E T A)$ receptor increases endogenous NO generation. Circulation 97:752-756.

Weibel ER (1997). Practical methods for biological morphometry: Stereological methods. London: Academic Press, 9-150.

Wolf SC, Brehm BR, Gaschler F, Brehm S, Klaussner M, Smykowski J, Amann K, Osswald H, Erley CM, and Risler T (1999). Protective effects of endothelin antagonists in chronic renal failure. Nephrol Dial Transplant 14(Suppl 4):29-30.

Zollinger HU and Mihatsch MJ (1978). Diabetic glomerulosclerosis. In: Zollinger HU, Mihatsch MJ, editors. Renal pathology in biopsy. New York: Springer Verlag, 391-399. 